\title{
Relationship marketing in Pasargad Bank
}

\author{
Naghmeh NADERVANDI $^{1}$, Ali Esmaeli Zadeh MoghareBI ${ }^{2}$, Mehdi SABOKRo $^{3, *}$ \\ ${ }^{1}$ Department of Business administration, E-Campus, Islamic Azad University, Tehran, Iran, \\ ${ }^{2}$ Associate Professor, Eslam Shahr branch, Islamic Azad University, Tehran, Iran, \\ ${ }^{3}$ Assistant Professor of Business Administration, Yazd University, Yazd, Iran, \\ "Corresponding author: msabokro@yazd.ac.ir
}

\begin{abstract}
Nowadays, maintaining and developing the capabilities of the organization depends not only on providing top-quality services, but also on the ability to attract customers and faithful them by creating favorable conditions. Relationship marketing is an important tool that can provide these conditions for customers. The purpose of this research was to investigate this factor and its impact on brand quality. The statistical population included the customers of Pasargad Bank in Tehran. In order to collect data, after determining sample size by Cochran formula to the extent of 384 individuals, the standard questionnaires were used. The method of the present study is quantitative research that has been conducted in descriptive method. The face validity was determined by management professors and the reliability was determined by relevant software and Cronbach's alpha. Descriptive and inferential statistical tests were used to test hypotheses and finally, the results of structural equation modeling showed that providing favorable conditions by relationship marketing can affect the quality of Bank and also attract customers.
\end{abstract}

Keywords: Customer, Relationship marketing, Service Delivery, Pasargad Bank.

\section{Introduction}

Companies have found that losing customers is something more than losing a sale item, but also it means losing the entire stream of purchases that a customer can do in his/her lifetime or in the period of being a customer (Kotler, 1999). Relationship marketing, like many new business ideas, has been widely used recently. But it is necessary to investigate more, because there is a lot of doubts about it. In terms of concept, relationship marketing placed in a set of marketing tactics that analyzes the interaction between buyers and sellers. For some people, relationship marketing is just a database of customers. While its core concept refers to commitment and trust. The present study examines the effects of relationship marketing approach on brand quality in Iranian Banking industry. It should be noted that the implementation and devising appropriate strategies and guidelines for increasing market share in banking industry leads to long-term profitability and survival (Ebrahim Pour Ahandani, 1391). Accordingly, the current study examines the effect of relationship marketing on brand quality in Pasargad Bank.

In today's competitive world, customers are one of the most important factors for organizational success and their retention and satisfaction are so important for any organization. 
In this regard, relationship marketing is one of the newest fields in customer- orientation (Hesaraki, 1393). Over the past decade, as a result of some factors, such as unclear boundaries between markets or industries, rapid changes in customer consumption patterns, shortening of product life cycle and amplification of customer awareness, the importance of relationship marketing has emerged as a key point in business strategies (Shes, 2002).

\section{Relationship marketing}

The concept of relationship marketing from a company perspective can be seen as a successful business philosophy or as a distinctive organizational culture or value that put the buyer- seller relationship at the strategic center or operational thinking of the company. The assumption of this research, according to previous studies of Callaghan (1995), Morgan and Hunt (1994), Wilson and others is that relationship marketing is a one- dimensional construct consisting of six components: Trust, Bonding, Communication, Shared value, Empathy and Reciprocity.

\subsection{Trust}

In all businesses, implementation of all policies, even in private life and in fact, in all relationships that exist between humans, trust has been identified as an essential element of success. Kenett Arrow (1975) believed that much of the economic backwardness in the world can be explained by the lack of trust (Amirshahi et al. 1388). In fact, trust is an important element of building long-term relationship in marketing, which means that the tendency to establish long-term relationship is based on transactional trust and it is an inalienable part of it. In social psychology, trust includes two main factors: counter-party confidence and trust in benevolence. Integrity means believing that correspondent will perform his word. Benevolence means believing that correspondent cares about the welfare of the organization and refrain from doing unexpected things that have a negative effect on it (Alrubaiee \& Al-Nazar, 2010).

\section{2-2. Bonding}

Bonding is a part of business relationship that engenders between the parties to the transaction (buyer- seller) during a way to achieve a desired goal. Shani and Chalasani (1992) in their identification of the bond developing between consumer, supplier, and product through the application of relationship marketing. Its application to relationship marketing consists of developing and enhancing consumer loyalty, which results directly in feelings of affection, a sense of belonging to the relationship, and indirectly in a sense of belonging to the organization or as Levitt (1983) described, developing and enhancing a long-term relationship (a bonded relationship) with the seller.

\section{2-3. Communication}

Morgan and Hunt (1994) define shared values as, "the extent to which partners have beliefs in common about what behaviors, goals and policies are important, unimportant, appropriate or inappropriate, and right or wrong". Nowadays, there is a new look to communication that communication is a mutual dialogue between company and its customers which happens before, during and after a sale. Communication in relationship marketing means keep in touch with valued customers, providing timely and accurate information about services, changes in services, 
and communicating actively during the creating problem. In fact communication is the process of creating mental unity between sender and recipient (Canon, 1997). Kotler (2005), Hawkins et al. (2001), and Ahmad and Buttle (2002) concluded that it is necessary to integrate all marketing communication messages in order to create, maintain and strengthen relationship with consumers and therefore successful relationship marketing (Alto et al. 2010).

\section{2-4. Shared value}

Shared value is defined as the extent to which partners have beliefs in common about what behaviors, goals, and policies are important or unimportant, appropriate or inappropriate, and right or wrong (Morgan and Hunt, 1994). Shared value has long been considered as an important dimension in building buyer- seller relationships. As a result when parties have common goals and values, they will be more committed to their relationship (Sin et al. 2010).

\section{2-5. Empathy}

Empathy is the dimension of a business relationship that enables the two parties to see the situation from the other person's perspective. In the service marketing literature, the dimension of empathy is used by Berry et al. (1990) in developing the SERVQUAL test instrument for service quality.

\section{2-6. Reciprocity}

Reciprocity is the dimension of a business relationship that occurs either party to provide favors or make allowances for the other in return for similar favors or allowances to be received at a later date (Callaghan et al. 1995).

\section{Brand Quality}

Brand marketers must pay attention to the response consumers have to brands, brand marketing activities and brand information sources. The final step is to focus on interpreting brand perception and brand image in a way that a close relationship between consumers and the brand is formed. Most importantly, in predetermined periods, they have to reevaluate changes in brand relations din order to acquire a better understanding of the brand experiences, which can contribute to redesigning and updating desirable and satisfactory brand relations (ibid.). Various researchers provide different definitions for quality services. However, all these scholars are in consensus regarding the fact that quality is defined based on requirements and needs of the customer. Quality services are those services which satisfy the expectations of the customer. High quality services or products are the main element and factor in successful organizations. Therefore, satisfaction and experience of the customer are the inevitable component of quality (Darvishi and Darvishi, 2014).

Another group of scholars define perceived quality as the perceptions of the customer regarding the general quality or superiority of goods or services compared to those of the other competitors (Atilgan and Akinci, 2005). According to Lanza (2008) perceived quality is the belief of the customer in the fact that the brand has a superior quality. Therefore, the superior 
quality perceived by the customer for the brand will increase the economic value of the data if they have a low quality. Generally, perceived quality involves the judgment and the belief of the customer regarding the superiority of a product or service compared to those of the competitors. During the process of increasing the perceived quality, the customer will decide on the quality of the product by comparing the perceived function of the product and services with what he or she expected (Erenkol et al., 2010). According to researched, perceived quality is an integral component influencing brand equity since it can affect the willingness to pay higher amounts, the intent to purchase that brand and the intent to select that brand. Brand's perceived quality not only affects the other dimension of the brand, but also it influences the classification of the products from the point of view of the customer (Acker, 1996).

\section{Influence of Relationship marketing orientation on brand quality}

Financial service institutions, particularly banks, try to create brand identity so that it can help them reach a competitive edge in the minds of clients, employees, and investors. How well and how quickly a bank improves or transitions its brand name will have a direct influence on its ability to manage good relations with the clients (Sweeny and Swait, 2008). In this regard, it has been recommended that the strategy of relational marketing be used for establishing brand equity in banks (Ndubisi, 2007).

Callaghan et al. (1995) and Morgan and Hunt (1994) proposed RMO (relational marketing orientation) as a multi-dimensional structure which encompasses six components: trust, working relationship, relation, common values, sympathy, and mutual relation.

\section{Background}

In this section, a number of studies carried out which are somewhat related to the subject of the current paper are briefly introduced.

In a study on the influence of media mix elements of brand equity (case study of Sina Bank in Iran), Farhangi and Abedini (2015) conclude that the frequency of advertisement in all the prominent media has a positive impact on the brand equity of both groups of clients in Sina Bank. Moreover, television was identified as the most influential media on repeat clients and sponsoring was identified as the most effective media on the brand equity of first-time customers.

Kadivar (2015) investigated the effects of the customers' perceptions source country of the brand on the brand equity of customers and concluded that the perceptions of the customers regarding the source country of the brand had a significant impact on the brand equity of the products.

Hesaraki (2014) carried out a study for measuring the relationship between relational marketing and the satisfaction of the insured (customers) in Asia Insurance Company. The results of the Spearman's test indicated a significant relationship between relational marketing 
and its components and the satisfaction of the clients of Asia Insurance Company and trust was identified as the most important component of relational marketing. Moreover, there was a significant relationship between the history of working of customers with Asia Insurance Company and their satisfaction. Furthermore, all the research variables were satisfactory.

Studying the relationship between the quality of electronic services and the brand quality, Kao and Lin (2016) concluded that there was a significant relationship between the quality of electronic services and brand quality. The results of the study have shown that brand quality also has a significant impact on the performance of the company.

Liu and Chou (2016) carried out a study on the effects of social media on the relations of relational marketing and perceptions of the brand quality and concluded that social media had a significant impact on improving the business relations between customers and the company and among the employees of the company. Furthermore, there was a significant relationship between relational marketing and perceptions of brand quality, with social media playing a significant role.

Abd Wahab et al. (2016) studied the relationship between relational marketing and customer loyalty and the mediatory role of customer satisfaction to conclude that there was a significant relationship between relational marketing and customer loyalty. The results also show that customer satisfaction has a significant mediatory impact on the relationship between relational marketing and customer loyalty.

Studying the effects of customer value and the relation between the company and the customers and the brand quality, Tasci (2016) concluded that customer value and the relations between the company and the customers had a positive and significant impact on brand quality.

Studying the effects of word of mouth advertisement on brand quality, Virvilaite et al. (2015) concluded that word of mouth advertising had a significant impact on brand quality.

Investigating the effects of intergenerational relations on brand quality, Cai et al. (2015) concluded that intergenerational relation had a significant impact on improving attitudes towards brand quality and tendency to buy products and services again, while it also affected the performance of the organization.

\section{Research model}

The aim of this study was to evaluate the effect of relationship marketing on brand quality of Pasargad bank in Tehran. So our variables are: Attitude toward relationship marketing and brand quality and they can be drawn up as following conceptual model: 


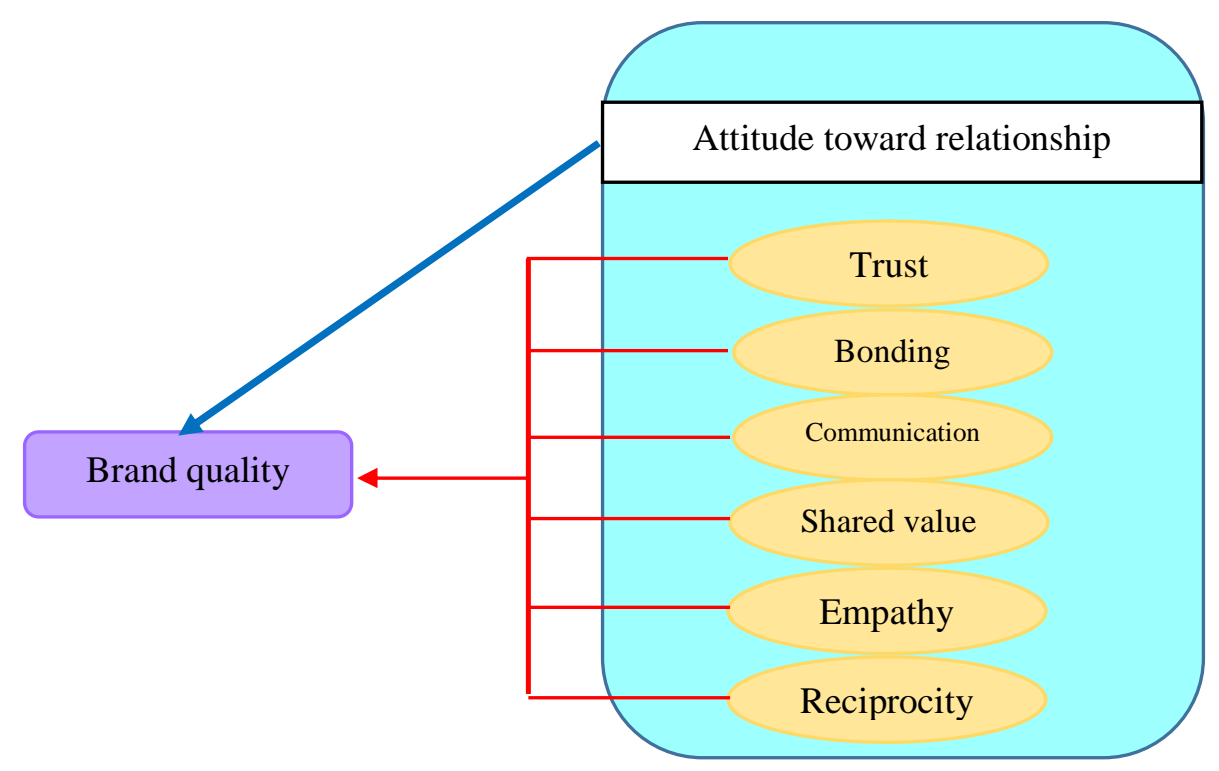

\section{Research hypothesis:}

\section{7-1. Main hypothesis:}

Relationship marketing has an effect on brand quality in Pasargad Bank.

\section{7-2. Sub hypotheses:}

1. Trust has an effect on brand quality in Pasargad Bank.

2. Bonding has an effect on brand quality in Pasargad Bank.

3. Communication has an effect on brand quality in Pasargad Bank.

4. Shared value has an effect on brand quality in Pasargad Bank.

5. Empathy has an effect on brand quality in Pasargad Bank.

6. Reciprocity has an effect on brand quality in Pasargad Bank.

\section{Methodology}

This study is a kind of applied research and has been conducted in descriptive research. In order to collect theoretical data procedure library was used and questionnaire was used in field method. The statistical population of research consisted of Pasargad bank customers in Tehran.

To determine minimum required sample size, Cochran formula was used for infinite population. The required sample size was 384 and 400 questionnaires were distributed between them and of these 362 were completed. 
Bulletin de la Société Royale des Sciences de Liège, Vol. 86, special edition, 2017, p. 929 - 943

Table 1: Questionnaires

\begin{tabular}{|l|l|c|c|}
\hline Variable & $\begin{array}{c}\text { Number of } \\
\text { Questions }\end{array}$ & $\mathbf{N}^{\circ}$. \\
\hline \multirow{4}{*}{ Attitude toward relationship marketing } & Trust & 4 & $1-4$ \\
\cline { 2 - 4 } & Bonding & 4 & $5-8$ \\
\cline { 2 - 4 } & Communication & 3 & $9-11$ \\
\cline { 2 - 4 } & Shared value & 4 & $12-15$ \\
\cline { 2 - 4 } & Empathy & 3 & $16-18$ \\
\cline { 2 - 4 } & Reciprocity & 3 & $19-21$ \\
\hline Brand quality & & 7 & $22-28$ \\
\hline
\end{tabular}

In order to assess the suitability of measuring tools we considered validity and reliability of them. For this purpose questionnaires were given to academic advisors and consultant professor. They were approved with minor modifications. For assessing the reliability of measurement instruments Cronbach's Alpha was used.

Table 2: Reliability of instruments

\begin{tabular}{|l|l|c|}
\hline \multirow{2}{|l|}{ Variable } & $\begin{array}{c}\text { Cronbach's } \\
\text { Alpha }\end{array}$ \\
\hline \multirow{4}{*}{ Attitude toward relationship marketing } & Trust & 0.71 \\
\cline { 2 - 3 } & Bonding & 0.76 \\
\cline { 2 - 3 } & Communication & 0.79 \\
\cline { 2 - 3 } & Shared value & 0.75 \\
\cline { 2 - 3 } & Empathy & 0.81 \\
\cline { 2 - 3 } & Reciprocity & 0.73 \\
\hline Brand quality & & 0.79 \\
\hline
\end{tabular}

\section{Descriptive Statics}

The sample consisted of $62 \%$ male and $38 \%$ female that $78 \%$ of all were married. The majority of sample were over 36 years and only $4 \%$ of the sample were less than 25 years. In terms of educational qualifications, the majority of sample (305\%) had master degree, $15 \%$ of them had associate degree, $9 \%$ had bachelor and $24 \%$ had $\mathrm{PhD}$ and higher that represents the educated people and people with high level of academic education in Pasargad Bank.

\section{Inferential Statics}

\section{Kolmogorov-Smirnov test for normality of variables}

According to table 3 the significance level for all dimensions of relationship marketing and brand quality is greater than 0.05; so the data are normally distributed and Parametric tests were used to analyze for them. 
Bulletin de la Société Royale des Sciences de Liège, Vol. 86, special edition, 2017, p. 929 - 943

Table 3: Distribution of research data

\begin{tabular}{|l|l|c|c|l|}
\hline \multicolumn{1}{|c|}{ Index } & Significance level & Assuming approval & \multicolumn{1}{c|}{ Conclusion } \\
\hline 1 & Trust & $0 / 056$ & $\mathrm{H}_{1}$ & Normal distribution \\
\hline 2 & Bonding & $0 / 088$ & $\mathrm{H}_{1}$ & Normal distribution \\
\hline 3 & Communication & $0 / 057$ & $\mathrm{H}_{1}$ & Normal distribution \\
\hline 4 & Shared Value & $0 / 066$ & $\mathrm{H}_{1}$ & Normal distribution \\
\hline 5 & Empathy & $0 / 074$ & $\mathrm{H}_{1}$ & Normal distribution \\
\hline 6 & Reciprocity & 0083 & $\mathrm{H}_{1}$ & Normal distribution \\
\hline & Relationship Marketing & $0 / 064$ & $\mathrm{H}_{1}$ & Normal distribution \\
\hline 7 & Brand quality & $0 / 063$ & $\mathrm{H}_{1}$ & Normal distribution \\
\hline
\end{tabular}

It is necessary to evaluate the adequacy of the sample before using LISREL structural equation; so we used KMO sampling adequacy test.

Table 4: Olkin test

\begin{tabular}{|l|l|c|}
\hline Olkin test & $0 / 847$ \\
\hline \multirow{3}{*}{ Bartlett's test of sphericity } & Bartlett's sphericity index & $5841 / 218$ \\
\cline { 2 - 3 } & Degrees of freedom & 1284 \\
\cline { 2 - 3 } & significance level & $0 / 002$ \\
\hline
\end{tabular}

Sufficient number of sampling is 0.847 . So sample size is suitable for using structural equation.

By using models using standard coefficients we concluded that there is significant correlation between the latent variables and their corresponding indexes. Factor loadings for All indicators intended for all questions related to variables of model are higher than 0.4.

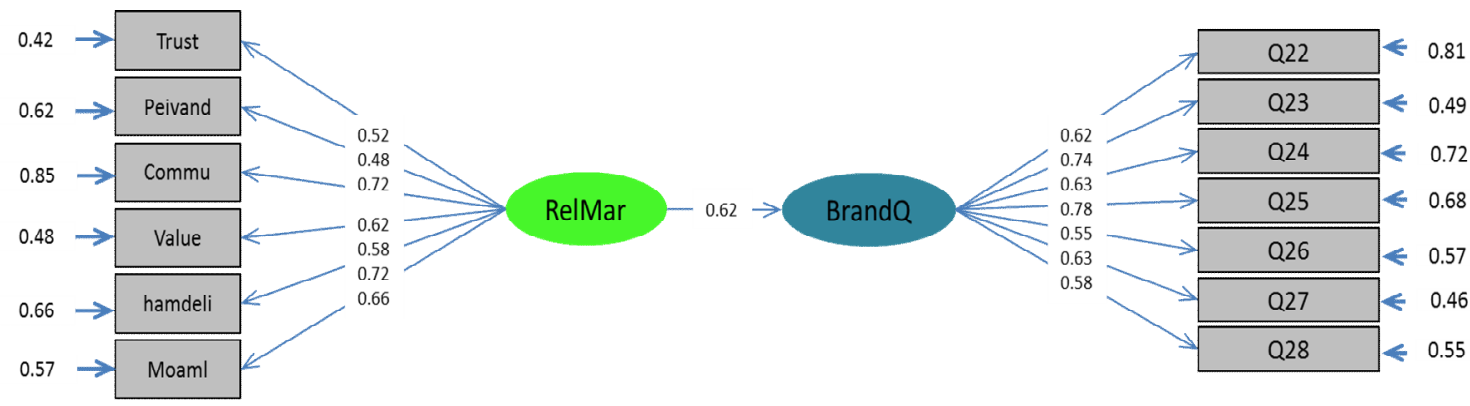

Chi-square $=1014.21, \mathrm{df}=451, \mathrm{p}$-value $=0.00000, \quad$ RMSEA $=0.007$

Figure 2: Standard estimates 


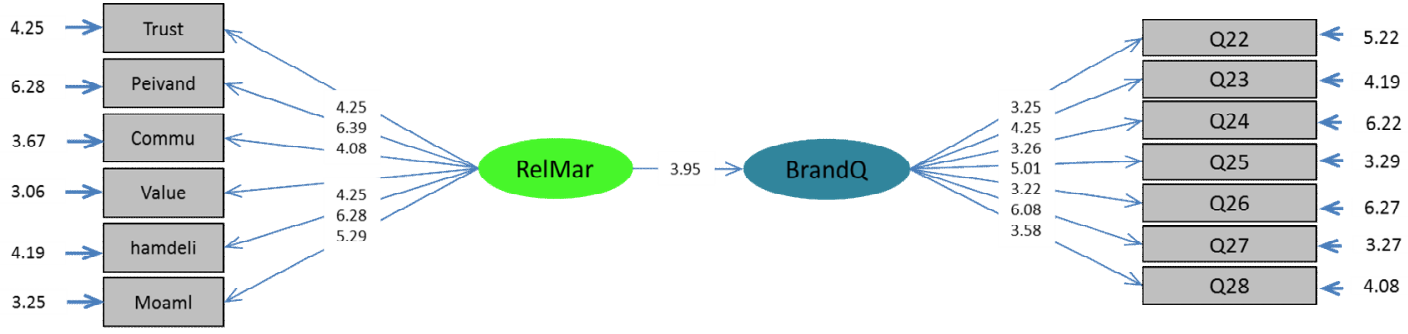

Chi-square $=1014.21, \mathrm{df}=451, \mathrm{p}$-value $=0.00000, \quad \mathrm{RMSEA}=0.007$

Figure 3: Significant mode

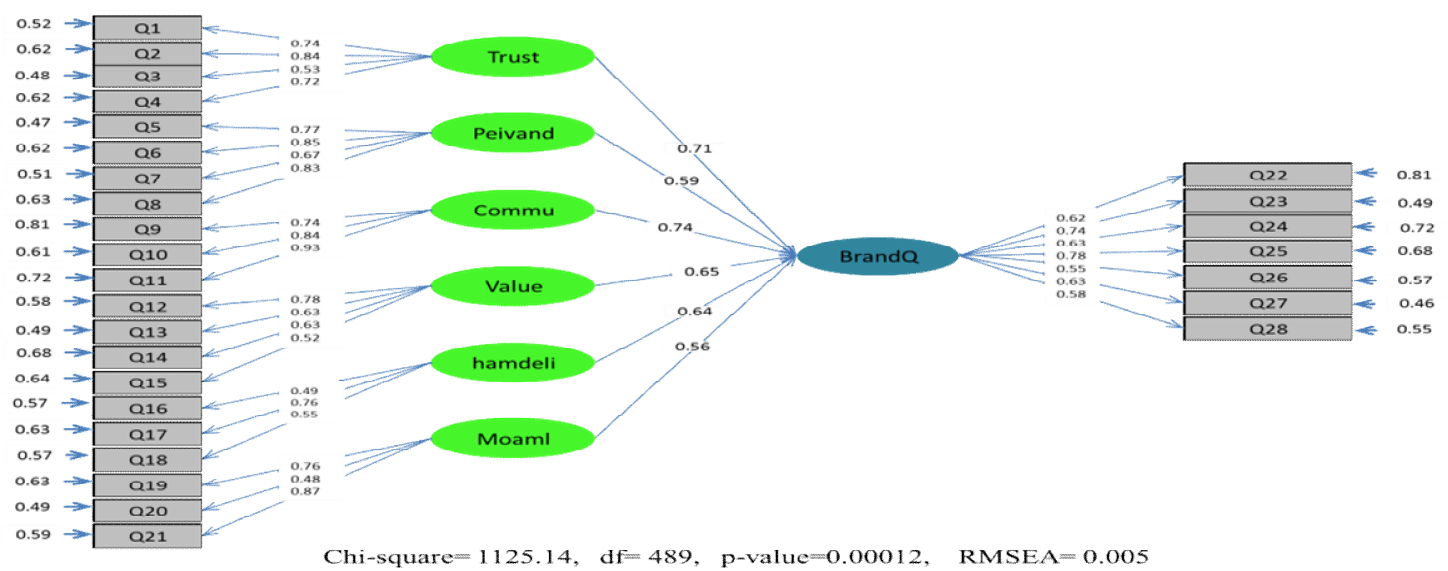

Figure 4: Secondary research hypotheses in the standard estimate

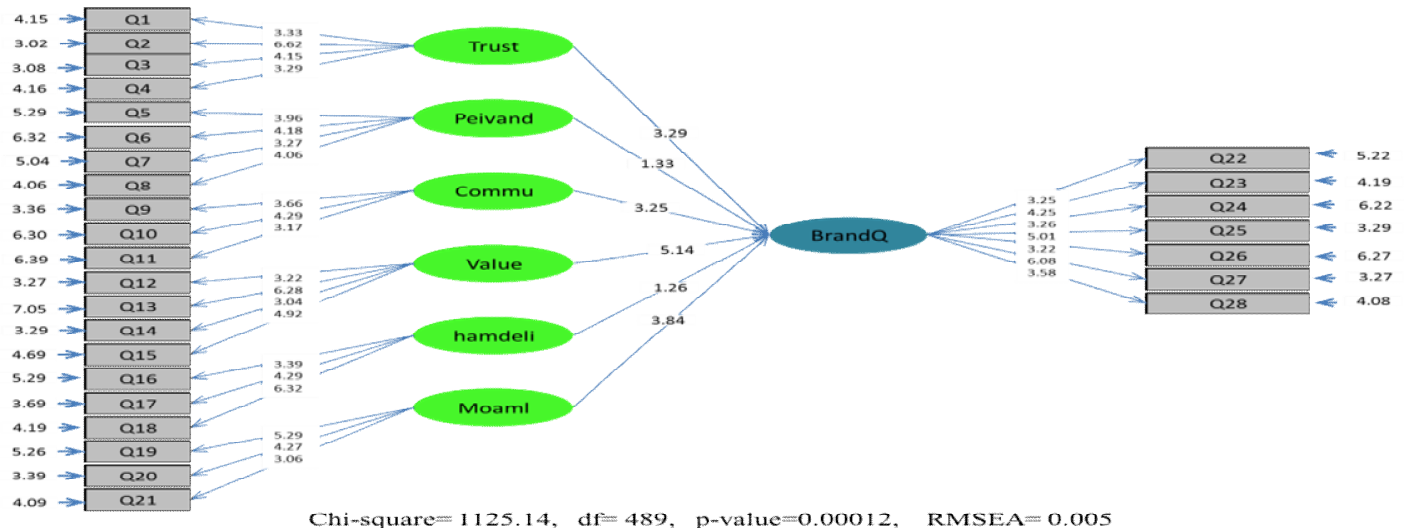

Figure 5: Secondary research hypotheses in the significant mode

The purpose of determining model fitting is to find out the consistency of a model with relevant data. Accordingly, we described model fitting of the final research model in table 5. 
Bulletin de la Société Royale des Sciences de Liège, Vol. 86, special edition, 2017, p. 929 - 943

Table 5: Fitting of the final research model

\begin{tabular}{|c|c|c|c|}
\hline Index & Accepted range & Value & Result \\
\hline $\mathrm{X}^{2} / \mathrm{df}$ & $\mathrm{X}^{2} / \mathrm{df} \leq 3$ & $2 / 30$ & Confirmed \\
\hline RMSEA & RMSEA $<0.09$ & $0 / 005$ & Confirmed \\
\hline GFI & GFI $>0.9$ & $0 / 92$ & Confirmed \\
\hline AGFI & AGFI $>0.85$ & $0 / 91$ & Confirmed \\
\hline CFI & CFI $>0.90$ & $0 / 92$ & Confirmed \\
\hline IFI & IFI $>0.90$ & $0 / 91$ & Confirmed \\
\hline
\end{tabular}

All of the fit indexes used in the present study showed that the model fits the data well. So it has a high ability to measure the main variables.

Table 6: Results of hypothesis test

\begin{tabular}{|l|l|c|c|c|}
\hline & Hypothesis & $\begin{array}{c}\text { Significance } \\
\text { level }\end{array}$ & $\begin{array}{c}\text { Normalized } \\
\text { Value }\end{array}$ & Result \\
\hline Main & $\begin{array}{l}\text { Relationship marketing has an effect on brand quality } \\
\text { in Pasargad Bank. }\end{array}$ & $3 / 95$ & $0 / 62$ & Confirmed \\
\hline Sub. 1 & $\begin{array}{l}\text { Trust has an effect on brand quality in Pasargad } \\
\text { Bank. }\end{array}$ & $3 / 29$ & $0 / 71$ & Confirmed \\
\hline Sub. 2 & $\begin{array}{l}\text { Bonding has an effect on brand quality in Pasargad } \\
\text { Bank. }\end{array}$ & $1 / 33$ & $0 / 59$ & Rejected \\
\hline Sub. 3 & $\begin{array}{l}\text { Communication has an effect on brand quality in } \\
\text { Pasargad Bank. }\end{array}$ & $3 / 25$ & $0 / 74$ & Confirmed \\
\hline Sub. 4 & $\begin{array}{l}\text { Shared value has an effect on brand quality in } \\
\text { Pasargad Bank. }\end{array}$ & $5 / 14$ & $0 / 65$ & Confirmed \\
\hline Sub. 5 & $\begin{array}{l}\text { Empathy has an effect on brand quality in Pasargad } \\
\text { Bank. }\end{array}$ & $1 / 26$ & $0 / 64$ & Rejected \\
\hline Sub. 6 & $\begin{array}{l}\text { Pasargad Bank. } \\
\text { Peciprocity has an effect on brand quality in }\end{array}$ & $3 / 84$ & $0 / 56$ & Confirmed \\
\hline
\end{tabular}

\section{Discussion and Conclusion}

Relationship marketing has a positive and significant impact on brand quality.

Trust has a positive and significant impact on brand quality.

Bonding has a positive impact on brand quality, but its impact isn't significant.

$\checkmark$ Communication has a positive and significant impact on brand quality. 
$\checkmark$ Shared value has a positive and significant impact on brand quality.

$\checkmark$ Empathy has a positive impact on brand quality, but its impact isn't significant; in other words, there isn't any significant relationship between empathy and brand quality from the perspective of Pasargad bank customers in the current research.

$\checkmark$ Reciprocity has a positive and significant impact on brand quality.

Marketing is one of the tools which can increase the growth of banking revenues. According to the managers of famous banks around the world only five percent of the customers' account for more than 85 percent of the profits of the banks (Nateghpour and Karami, 2014). Moreover, the studies of economists show that by increasing high-priority customers and creating effective satisfaction among the customers, banks can increase their profitability in a remarkable fashion. Therefore, it is recommended that in the competitive world of modern banking, banks try to find ways to retain their customers. The only way to achieve this is through relational management and effective customer orientation. Nowadays, it is undeniable that customers have a much higher access to opportunities for comparing services and their financial management has grown more complex. Therefore, creative relations between customers and banks and the set of quality services and the nature of purchased services depend on the quality of the interaction and the relation between the customer and the bank.

In the following, considering the role of relational marketing in providing services, we provide some recommendations for Pasargad Bank which are in accordance with the results and conditions emphasized by the research data.

\section{Suggestions}

Describe banking service, especially electronic banking service

$\checkmark$ Describe services perfectly through public media from their first step to the end

$\checkmark$ Using social network

$\checkmark$ Using different communication methods for each person, due to unique personality and behavior of each person

$\checkmark$ Training to employees how to communicate with customers, including training how to apologize especially to those employees who are constantly dealing with customers complaints

$\checkmark$ Showing empathy to customers 
Providing ancillary services besides core services in a way that distinguishes it from other services offered by competitors, including creating a club for valuable and loyal customers.

\section{References}

[1] Ebrahim Pour Ahandani, Atefeh. (1391). Investigating the relationship between relationship marketing and increasing market share in banking industry. Master's thesis, Gilan University.

[2] Amirshahi, Mir Ahmad; Siah Tiri, Vida; Ravan Bod, Fariba. (1388). Identify key factors affecting customer confidene in banks: Key customers in Kar Afarin Bank in Tehran. Management research in Iran.

[3] Hoseini, Seyed Mehdi; Nabavi, Seyed Ali; Nili, Mehdi. (1392). Assessing the relationship between brand trustworthiness of insurance companies and customer commitment. Researcher (Management). 10 (29), P 13- 24.

[4] Hesaraki, Amir hosein. (1393). Determining the relationship between relationship marketing and customer satisfaction in Asia Insurance. Master thesis, School of Management, Islamic Azad University, Tehran.

[5] Hoseini, Abolfazli and Rahimi. (1388). Investigating the effect of brand equity on consumer response (Case Study: Iranol). Journal of management perspective, No 32.

[6] Danesh Amooz, Najmeh. (1393). Relationship marketing and its impact on customer loyalty, Investigate the role of satisfaction and service quality (Case study: Selected branches of Tejarat Bank in Tehran). Master thesis, Faculty of management and Economics, Tarbiat Modarres University.

[7] Daemi, Shahab. (1388). The effect of matching brand personality, perceived quality and brand image on brand loyalty. Publication: Marketing management.

[8] Rezaei, Abbas. (1387). The effect of relationship marketing techniques on relationship quality (Case study: Kar Afarin Insurance agencies in Mashhad). Master thesis, Faculty of Economics and Administrative sciences, Ferdowsi University.

[9] Sobhani. (1389). Determining the role of gender in investigating the effect of relationship marketing strategy on customer loyalty in travel agancies in Neishabur. Master thesis, Ferdowsi University, Mashhad.

[10] Setoodeh Sharifi, Emad. (1392). Investigating factors effecting relationship marketing in buyer- seller relations (Case study: Bahman Diesel). Journal: Executive management, Vol 3, No 5, P 29- 52.

[11] Sahebi, Farideh. (1390). Investigating the relationship between trust and continuation of relation in industrial marketing (B2B), Case study: Medium and large industrial units in Zanjan. Master thesis, Faculty of humanities and social sciences, University of Tabriz.

[12] Zohoori, Bahareh. (1388). The effect of relationship marketing dimensions on customer loyalty to the brand of cell phones. Master thesis, Faculty of management, Tehran University.

[13] Farhangi, Ali Akbar and Abedini, Razieh. (1394). The effect of media mix elements on brand equity services (Case study: Sina Bank). Marketing management (26)10, P 47- 74. 
[14] Kamali Nejad, Rahman. (1389). The relationship between relationship marketing methods and repurchase in retail chain stores in Gorgan. Journal: Management researcher, Vol 10, No 30, P 57- 72.

[15] Noori Nafari, Mehran. (1389). Analysis of barriers and constraints in implementation of relationship marketing in tourism industry by using Fuzzy MCDM. Journal: marketing management, Vol 6, No 13, P 95- 114.

[16] Venous, Davar and Safaeian, Mitra. (1381). Marketing applications methods of banking services for Iranian banks. Publication: Knowledge Look.

[17] Hawkins, Dell, Clamps and minerals Roger Kenneth (1385). Consumer behavior, translated by Ahmad Roosta and Atieh Bathaei, Sargol publication, Tehran, Frist edition.

[18] Anderson, W. J. (2001). Deleterious effects of criminal victimization on women's health and medical utilization. Archives of Internal Medicine, 151, 342-357.

[19] Arasli H., Mehtap-Smadi S., and Katircioglu S. T., (2005), "Customer Service Quality in the Greek Cypriot Banking Industry”. Managing Service Quality. Vol. 15 No. 1. pp 41576.

[20] Berry, L and A. Parasuraman (1993), "The Nature and Determinants of Customer Expectations of Service," Journal of the Academy of Marketing Science, 21 (I), 1-12.

[21] Cai, Y., Zhao, G., He, J. (2015). Influences of two modes of intergenerational communication on brand equity. Journal of Business Research, 68(3), 553-560.

[22] Callaghan, M. B., McPhail, J., and Yau, O. H. M. (1995), "Dimensions of a Relationship Marketing Orientation - An Empirical Exposition," in World Marketing Congress, Ken Grant and Ian Walker, Eds. Melbourne, Australia: Academy of Marketing Science. VII-II, 1059-66.

[23] Chang, P., Chieng, M., (2006), "Building Consumer Brand Relationship: A Cross-Cultural Experiential View”, Psychology \& Marketing, Vol.23, No.11,PP.927-959, DOI: 10.1002/ mar.20140.

[24] Chattananon A, Trimetsoontorn J. 2009. Relationship marketing: a Thai case, Journal of Business \& Industrial Marketing, Vol. 14 No. 2, pp. 1- 13.

[25] Cropanzano and Mitchell, 2005 - R. Cropanzano and M.S. Mitchell, Social exchange theory: An interdisciplinary review, Journal of Management 31 (2005), pp. 874-900.

[26] de Chernatony, L. and Dall'Olomo Riley, F. (1992), "Defining a "brand". Beyond the Literature with experts", Joumal of Marketing Management, Vol. 14, No. 4/5, pp. 417-443.

[27] Dhanushanthini Yoganathan et al., (2015), The influence of relationship marketing orientation on brand equity in banks, Journal of Retailing and Consumer Services, ,No. 26 ,pp: 14-22.

[28] Dibb, Sally and Maureen Meadows (2001), "The Application of a Relationship Marketing Perspective in Retail Banking," The Service Industries Journal, 21(1), 169-194.

[29] Gilaninia,Sh;. Seyed Danesh.S.Y; Mousavian.S.J. (2011). Effective Factors in Green Supply Chain Management and Natural Environment Developed in Iran Tourism Industry: The Case of Small and Medium Tour Operators, International Journal of Business Administration, vol. 2, and no. 2. 
[30] Grönroos, Christian (2004), "The Relationship Marketing Process: Communication, Interaction, Dialogue, Value", Journal of Business \& Industrial Marketing, Vol. 19, No. 2, PP. 99-113.

[31] Hogan, B. E., Linden, W., \& Nagarian, B. (2002). Social support interventions: Do they work. Clinical Psychology Review, 22 (3), 381-440.

[32] Huo, S. and S. K. Xu, (2010), "The impact of parental brand attribute associations and affect on brand extension evaluation" Journal of Business Research, vol. 53 (3), pp. 111122

[33] Jalilvand, M. R., Shekarchizadeh-Esfahani, S., \& Samiei, N. (2011). Destination Branding and Tourists' Attitudes (The Case of Isfahan as a Tourism Destination in Iran). International Journal of Marketing Studies, 2 (2), 235-244.

[34] Kao, T., Lin, W. (2016). The relationship between perceived e-service quality and brand equity: A simultaneous equations system approach. Computers in Human Behavior, 57(1), 208-218.

[35] Morton,M. M.(2009).Evaluation of brand equity measures. further empirical results.The Journal of Product and Brand Management,10(1).38-51.

[36] Ndubisi, N. O. and Wah, C.K. (2005). Factorial and Discriminant analysis of the underpinnings of relationship marketing and customer satisfaction. International Journal of Bank Marketing, vol. 23, No. 7, pp. 542-557.

[37] Papasolomou I., Vrontis, D. (2006)«Using internal marketing to ignite the corporate brand: the case of the UK ratail bank industry», Journal of Brand Management, 14, P.177-95.

[38] Payne, R.J., Jassey, V.E.J., Leith, I.D., Sheppard, L.J., Dise, N.B. \& Gilbert, D. (2014) Ammonia exposure promotes algal biomass in an ombrotrophic peatland. Soil Biology and Biochemistry, 57, 936-938.

[39] Rashid, Tahir (2003), "Relationship Marketing: Case Studies of Personal Experiences of Eating Out", British Food Journal, Vol.105, No.10. PP. 742-750.

[40] Shes, Jagadish N. (2002), "The Future of Relation Marketing", Journal Of Services Marketing, Vol. 14, No. 7, PP. 590-592.

[41] Sin, Leo.Y.M, Tse, Alan.C.B, Yau, Oliver.H.M, Lee, Jenny.S.Y \& Chow, Raymond (2002), "The Effect Of Relationship Marketing Orientation on Business Performance in a Service- Oriented Economy", Journal of services marketing ,Vol. 16, No. 7, PP. 656-676.

[42] So, S. L. M., \& Speece, M. W. (2000). Perceptions of relationship marketing among account managers of commercial banks in a Chinese environment. International Journal of Bank Marketing, 18(7), 315-327. http://dx.doi.org/10.1108/02652320010359534.

[43] Svensson, E.(2001b) Construction of a single global scale for multi-item assessments of the same variable. Statistics in Medicine 20,3831-3846.

[44] Sweeney, J. Swait,J. (2008).The Effects of Brand Credibilityon Customer Loyalty. Journal of Retailing and Consumer Services, 15 (8), 179-193.

[45] Taleghani Mohammad, S. Gilaninia and S J Mousavian (2011), "The Role of Relationship Marketing in Customer Orientation Process in the Banking Industry with focus on Loyalty”, International Journal of Business and Social Science, Vol. 2, No.19. 
Bulletin de la Société Royale des Sciences de Liège, Vol. 86, special edition, 2017, p. 929 - 943

[46] Tasci, A. (2016). A critical review of consumer value and its complex relationships in the consumer-based brand equity network. Journal of Destination Marketing \& Management, $1(1), 12-26$.

[47] Too, L. H. Y., Anne L. Souchon, and Peter C. Thirkell (2001), "Relationship Marketing and Customer Loyalty in a Retail Setting: A Dyadic Exploration," Journal of Marketing Management, 17 (3/4), 287-319.

[48] Virvilaite, R., Tumasonyte, D., Sliburyte, L. (2015). The Influence of Word of Mouth Communication on Brand Equity: Receiver Perspectives. Procedia - Social and Behavioral Sciences, 213(2), 641-646.

[49] Ward, Tony \& Tracey Dagger (2007), "The Complexity of Relationship Marketing for Service Customers", Journal of Services Marketing, Vol. 21, No. 4, PP. 281-290.

[50] Yoganathan, K., Brown, D., Yoganathan, K., 2015. Remission of progressive multifocal leukoencephalopathy following highly active antiretroviral therapy in a man with AIDS. Int J Gen Med 5, 331-334.

[51] Zhou, X., 2009, "Reform the International Monetary System" (Beijing: People's Bank of China). Available via the Internet at http://www.china.org.cn/business/news/2009-3/24/content_17490662.htm . 